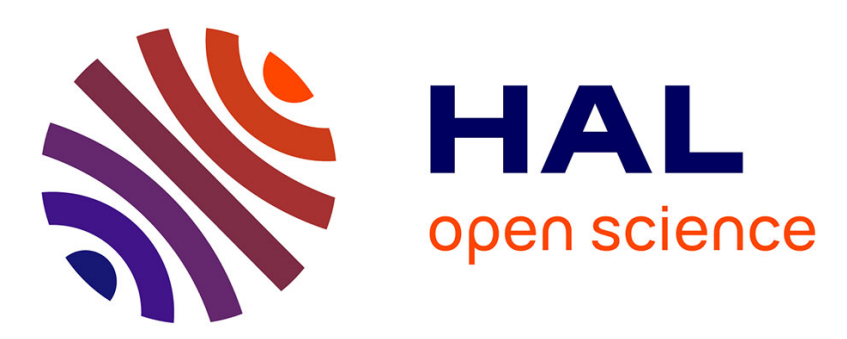

\title{
Double-layer Tedlar bags: a means to limit humidity evolution of air samples and to dry humid air samples
}

\author{
Stéphane Cariou, Jean-Michel Guillot
}

\section{To cite this version:}

Stéphane Cariou, Jean-Michel Guillot. Double-layer Tedlar bags: a means to limit humidity evolution of air samples and to dry humid air samples. Analytical and Bioanalytical Chemistry, 2005, 384 (2), pp.468-474. 10.1007/s00216-005-0177-4 . hal-03482825

\section{HAL Id: hal-03482825 \\ https://hal.mines-ales.fr/hal-03482825}

Submitted on 19 Jan 2022

HAL is a multi-disciplinary open access archive for the deposit and dissemination of scientific research documents, whether they are published or not. The documents may come from teaching and research institutions in France or abroad, or from public or private research centers.
L'archive ouverte pluridisciplinaire HAL, est destinée au dépôt et à la diffusion de documents scientifiques de niveau recherche, publiés ou non, émanant des établissements d'enseignement et de recherche français ou étrangers, des laboratoires publics ou privés. 


\section{Stephane Cariou · Jean-Michel Guillot \\ Double-layer Tedlar bags: a means to limit humidity evolution of air samples and to dry humid air samples}

\begin{abstract}
Tedlar bags, which are widely used to collect air samples, especially VOCs and odorous atmospheres, can allow humidity to diffuse when relative humidity levels differ between the inside and outside. Starting with dry air inside the bag and humid air outside, we monitored equilibrium times under several conditions showing the evolution and influence of collected volumes and exposed surfaces. A double-film Tedlar bag was made, to limit the impact of external humidity on a sample at low humidity level. With the addition of a drying agent between both films, the evolution of humidity of a sample can be stopped for several hours. When a VOC mixture was monitored in a humid atmosphere, humidity was decreased but no significant evolution of VOC concentrations was observed.
\end{abstract}

Keywords Tedlar bags - Air sampling · Humidity · Sample evolution $\cdot$ VOC

\section{Introduction}

Three types of sample collectors are often used to collect and transport air samples for later analysis: glass bubbles, stainless steel canisters and sample bags. However, each collector has several drawbacks. The glass bubbles are fragile, and their volume is limited. The canister is heavy and requires a special device for cleaning and air sampling. It is also considered as expensive equipment for occasional analysis. Researchers use canisters as air sampling collectors $[1,2]$. Tedlar bags are easy to manipulate and transport but are quite fragile (explosion or puncturing). They are used in various studies: for example, Tedlar bags

\footnotetext{
S. Cariou · J.-M. Guillot $(\bowtie)$

Ecole des Mines d'Alès, LGEI,

6 Avenue de Clavières,

30319 Alès Cedex, France

e-mail: jean-michel.guillot@ema.fr

Tel.: +33-466-78-2780

Fax: +33-466-78-2701
}

have been used to collected volunteers' exhaled air [3] and also used to sample indoor air [4].

The draft standard EN13725 "Air quality_determination of odour concentration by dynamic olfactometry" from the European Committee for Standardization [5] mentions suitable materials for samples bags:

- Polyvinyl fluoride, trade name Tedlar [6]

- Fluorinated ethylene propylene copolymer, trade name Teflon FEP

- Polyterephthalic ester copolymer, trade name Nalophan [7].

Tedlar is used because of its relative robustness and nonadsorption of VOCs. Heat sealing can be used with Tedlar as opposed to Nalophan. Tedlar bags have been used for testing solid-phase microextraction (SPME) in ambient air and workplace air [8]. Analytical standards were prepared by volumetric injection into Tedlar bags, and storage stability in the bags was studied. Stability was found to depend on the molecules taken into consideration. Aromatic compound levels were constant for $46 \mathrm{~h}$, while the levels of chlorinated compounds decreased by a factor of 2 or 3. Conservation of volatile sulphur compounds in Tedlar bags was difficult [9]. Recovery of these compounds did not exceed $50 \%$ after 6 days. Another study showed the adsorption levels of some VOCs on Tedlar bags [10].

To prevent loss of pollutants by diffusion, multilayer bags have been tested. For example, Cali-5-bond gas sampling bags might be used [7]. These bags are made of a sandwich foil consisting of five layers of materials comprising, from the outside air to the sample, a $75 \mu \mathrm{m}$ polyethylene sheet, a $40 \mu \mathrm{m}$ polyamide layer, $12 \mu \mathrm{m}$ aluminium foil, 3-4 $\mu \mathrm{m}$ polyvinyl dichloride (PVDC) and $12 \mu \mathrm{m}$ polyester (PTEP). The metal-coated multilayer Tedlar (MMT) bag suggested the use of a three-layer bag [11]. The inner and middle layers are made of Tedlar film and the outer one of Mylar, which is less permeable but less inert than Tedlar. The Nalophan bags seem to keep the odour concentration relatively stable for at least $12 \mathrm{~h}$ [7]. However, the concentration decreased after $30 \mathrm{~h}$ to approximately half of the original concentration. This work suggested that the conservation of odour sample in Nalophan is better than in a multilayer bag. In contrast to this 
work, a previous study explained that some permanent gases can be stored in MMT bags for at least 3 months without significant pollutant loss [11]. The authors compared recovery of $\mathrm{CO}, \mathrm{CH}_{4}$ and $\mathrm{CO}_{2}$ after storage in single Tedlar and MMT sampling bags. After 32 days in Tedlar bags, these gases showed recoveries of from $0 \%$ to $26 \%$, whereas in MMT bags after 75 days these gases exhibited recoveries of approximately $90 \%$ to $107 \%$. Another piece of research evaluated the storage of volatile sulphur compounds in different containers, in particular, Tedlar bags [12].

In this study, the diffusion of humidity inside Tedlar bags was monitored. The influence of the surface area and volume of the bag were evaluated. The evolution of moisture in a double Tedlar bag was also tested. Then, to limit moisture diffusion, a desiccant was put between the two layers of Tedlar. A humid VOC mixture was monitored to find out whether the diffusion of humidity from the sample to the intermediate layer containing the desiccant also affects the level of VOCs in the air sample.

\section{Methodology}

Tedlar bags

Tedlar bags were home made from $50 \mu \mathrm{m}$ Tedlar film, thickness at $69.9 \mathrm{gm}^{-2}$ (Micel, Cachan, France), and with a stainless steel valve. The film was thermally sealed with a sealer device type PHM 600 (MIC, Lisieux, France). Sealing time and cooling time were $0.45 \mathrm{~s}$ and $15 \mathrm{~s}$, respectively. Several types of bags were made:

Single-layer bags with different surface areas (on both sides): $0.3,0.5,1.1$ and $1.2 \mathrm{~m}^{2}$

Double-layer bags with surface areas of $1.2 \mathrm{~m}^{2}$ for the external bag and $0.5 \mathrm{~m}^{2}$ for the internal one, as illustrated in Fig. 1

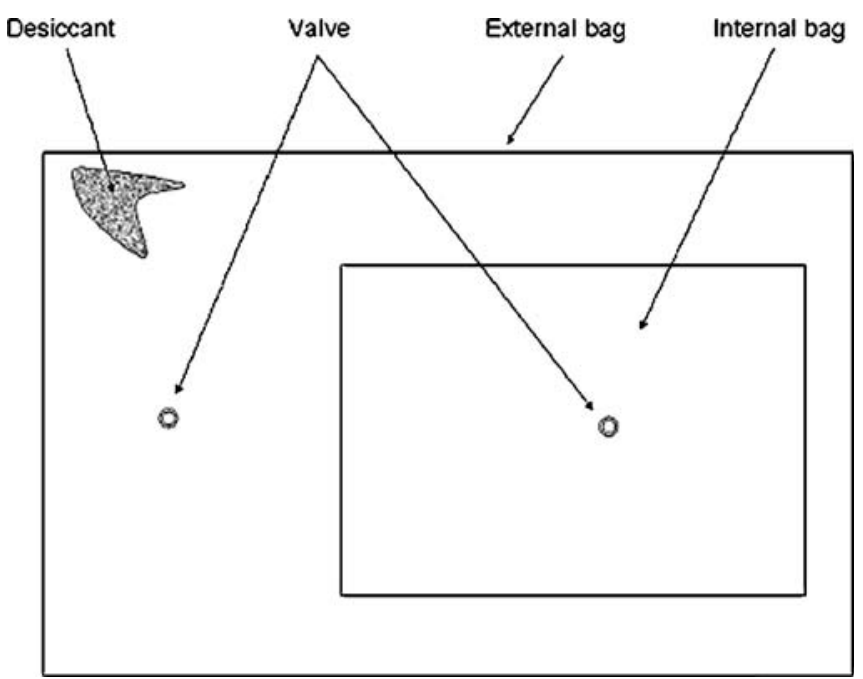

Fig. 1 Double-layer Tedlar bag with the possibility of incorporating desiccant inside

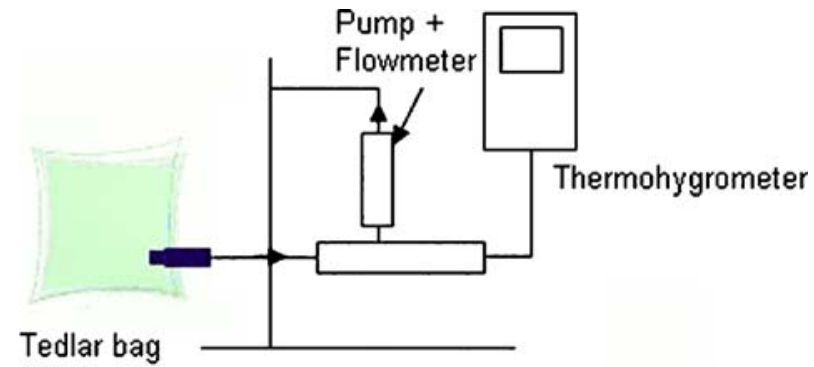

Fig. 2 System for measuring humidity of air samples

Humidity measurement

Relative humidity and temperature were measured with a Kimo HD 100 thermohygrometer, the characteristics of which are as follows:

1. Range of humidity from $5 \% \mathrm{rH}$ to $95 \% \mathrm{rH}$

2. Operating temperature from $0^{\circ} \mathrm{C}$ to $40^{\circ} \mathrm{C}$

3. Humidity and temperature accuracies $\pm 2 \%$ of value $\pm 1.8 \% \mathrm{rH}, \pm 2 \%$ of value $\pm 0.3^{\circ} \mathrm{C}$.

A small amount of the air sample was pumped at a $100 \mathrm{ml} \mathrm{min}^{-1}$ flow rate and transferred from the bag to a glass chamber, where measurement was carried out (see Fig. 2). Air from the bag was pumped for 2 min to stabilise the humidity level in the chamber.

\section{Behaviour of monolayer bags}

The experiments carried out to characterise monolayer bags are described in Table 1. As a first parameter, different sizes of bags were used and defined by the exposed surface area of Tedlar film (both sides of the bag). Air volume was chosen as a second parameter for these experiments.

Behaviour of double-layer bags

Experiments carried out to characterise doubler-layer bags are reported in Table 2. As shown in this table, the surface area of the bags was fixed in order to have an external bag surface four times greater than that of the internal bag. In the last condition described in Table 2, Drierite mass was fixed at $50 \mathrm{~g}, 100 \mathrm{~g}$ and $150 \mathrm{~g}$ for three experiments.

Table 1 Surface area and air volume used for experiments made with monolayer bags

\begin{tabular}{lll}
\hline Experiment & Surface $\left(\mathrm{m}^{2}\right)$ & Air volume (l) \\
\hline Impact of valve & 0.5 & 20 \\
Repeatability & 1.2 & 70 \\
Impact of volume & 1.2 & $25,50,75$ and 100 \\
Impact of surface area & $0.3,0.5,1.1$ and 1.2 & 10 \\
\hline
\end{tabular}


Table 2 Surface area and air volume used for experiments to characterise double-layer bags

\begin{tabular}{llllll}
\hline Experiment & \multicolumn{2}{l}{ Internal bag } & \multicolumn{2}{l}{ External bag } \\
\cline { 2 - 3 } \cline { 5 - 6 } & $\begin{array}{l}\text { Surface } \\
\left(\mathrm{m}^{2}\right)\end{array}$ & $\begin{array}{l}\text { Volume } \\
(\mathrm{l})\end{array}$ & $\begin{array}{l}\text { Surface } \\
\left(\mathrm{m}^{2}\right)\end{array}$ & $\begin{array}{l}\text { Volume } \\
(\mathrm{l})\end{array}$ \\
\hline $\begin{array}{c}\text { Impact of bag's } \\
\text { external volume }\end{array}$ & 0.3 & 15 & 1.2 & $\begin{array}{c}10,25,50 \\
\text { and } 75\end{array}$ \\
\begin{tabular}{c} 
Impact of Drierite \\
\hline
\end{tabular} & 0.3 & 15 & 1.2 & 70 \\
\hline
\end{tabular}

Test with VOC mixture in humid air sample

To control the effect of Drierite on the humidity decrease in a VOC mixture, a humid atmosphere $(151$ at $40 \%$ relative humidity) polluted by $250 \mathrm{\mu g} \mathrm{m}^{-3}$ of 2-propanol (IPA), toluene and 2-butanone (MEK) was injected into the internal bag (of a double-layer bag). In the external bag, 801 of dry air was set with $300 \mathrm{~g}$ of regenerated Drierite. Detection was conducted by SPME-GC-FID [13]. Many researchers use this sampling method to quantify small amounts of contaminants in air [14-16]. Extraction time was determined to avoid adsorption competition between components, as recommended in the literature [17]. In this work a PDMS-carboxen fibre (Supelco) was used for air sampling and the extraction time was set at $2 \mathrm{~min}$.

\section{Experimental design}

A $2^{2}$ factorial design was carried out to determine the influence of bag volume and surface area on humidity evolution in Tedlar bags. Table 3 presents the factors used in this experimental design. Experiments to complete the experimental design are shown in the experimental matrix presented in Table 4.

All experiments were conducted simultaneously to reduce the impact of external humidity and temperature. The data found were able to be used to build a model such that $\mathrm{Hr}=\mathrm{b}_{0}+\mathrm{b}_{1} \mathrm{~V}+\mathrm{b}_{2} \mathrm{~S}+\mathrm{b}_{12} \mathrm{VS}$. Experiments 5 and 6 were carried out to compare the model with experimental results. A software program called Nemrodw (LPRAI, Marseille, France) was used to solve the experimental design and calculate the impact factor of volume and surface area.

Table 3 Coded values of experimental design factors
Table 4 Experiments conducted in experimental design

\begin{tabular}{lll}
\hline Experiment & Volume & Surface \\
\hline 1 & -1 & -1 \\
2 & +1 & -1 \\
3 & -1 & +1 \\
4 & +1 & +1 \\
5 & 0 & 0 \\
6 & +0.33 & +0.71 \\
\hline
\end{tabular}

\section{Results}

\section{Testing of bags}

As home-made bags were used in this study, experiments were performed to evaluate the quality of the bags and especially the potential diffusion due to the valve. The importance of the valve in moisture diffusion was therefore estimated first. Two identical thermohygrometers, as described previously, were set in two bags built with and without a valve (the apparatus was placed totally in the bags and the dry air also before sealing). No significant differences were observed. In this way we could conclude that the construction was free of faults due to the valve. Then, experiments were carried out to control the repeatability of humidity measurement. A relative standard deviation of $2 \%$ was observed in the evolution of humidity in four identical Tedlar bags. This value is in the same range as the thermohygrometer accuracy.

\section{Evolution of humidity in single-layer Tedlar bags}

\section{Impact of the volume}

Four bags with the same surface area were filled with different volumes of dry air. The evolution of the humidity in the Tedlar bags was monitored until equilibrium was reached between internal and external levels of humidity (Fig. 3).

At the beginning of the experiment an increase in the relative humidity difference was observed. This event can be explained by an increase in the relative humidity of the room and the initial value of thermohygrometer. A decrease was observed in all the bags. Relative humidity in bags tended to room moisture levels, as observed by the decrease in the difference. The graph showed that the volume increase led to a rise in saturation time. In conclusion, a large volume of air is required in the bags to avoid rapid air sample contamination by humidity.

\begin{tabular}{lccc}
\hline Parameter & \multicolumn{3}{c}{ Coded value } \\
\cline { 2 - 4 } & -1 & 0 & +1 \\
\hline Volume (1) & 10 & 17.5 & 25 \\
Surface area & 0.5 & 0.85 & 1.2 \\
$\left(\mathrm{~m}^{2}\right)$ & & & \\
\hline
\end{tabular}

\section{Impact of the surface area}

To evaluate the impact of surface area, four Tedlar bags were filled with 101 of dry air. Fig. 4 shows the difference 
Fig. 3 Difference between internal humidity and room humidity in Tedlar bags with different volumes (initial relative humidity of the room was $25 \%$ )
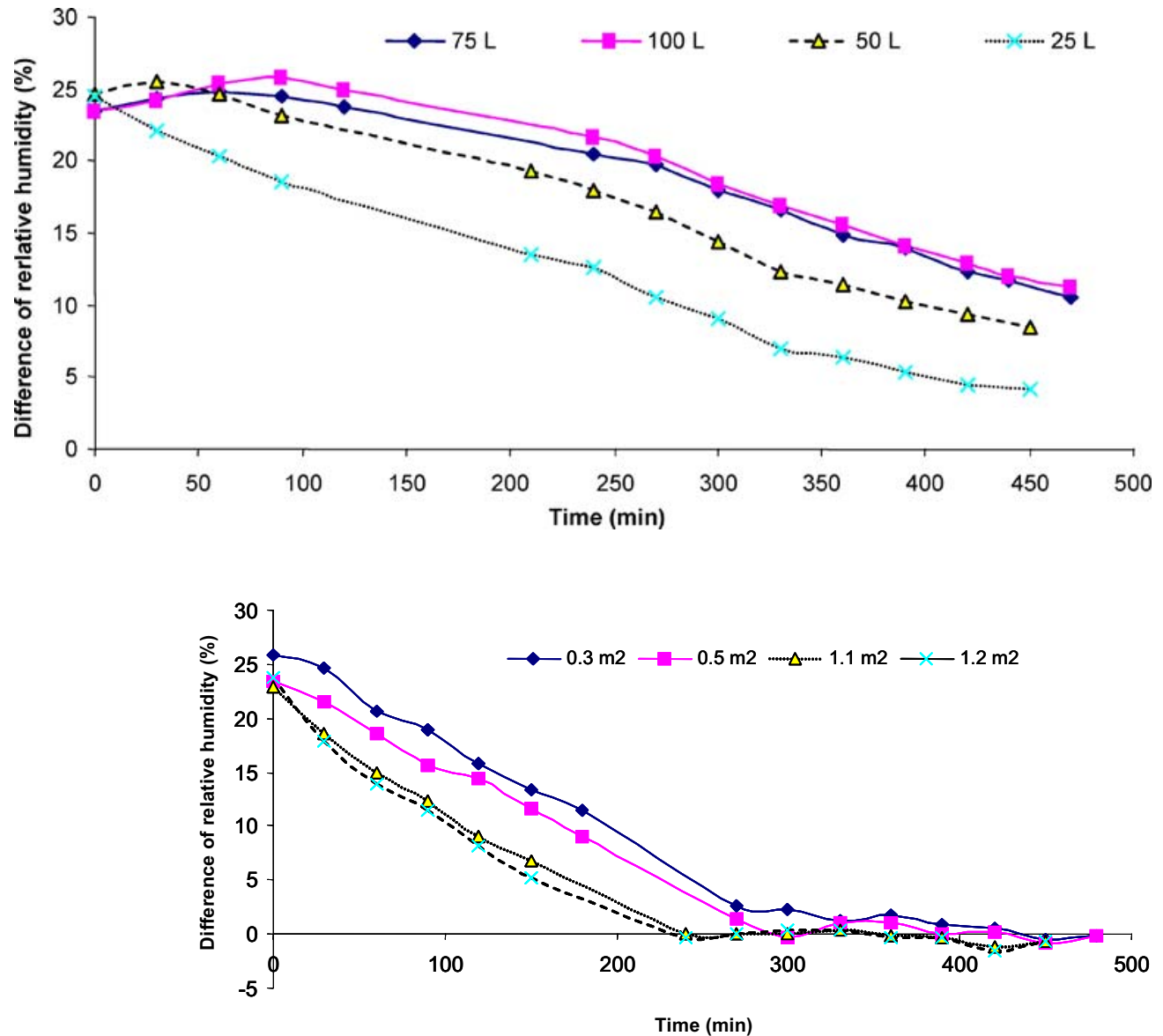

Fig. 4 Difference between inner moisture and room moisture with bags of different surface areas in relative humidity between the inside and outside of the bags. When the surface area was increased, saturation time decreased. With a $0.3 \mathrm{~m}^{2}$ bag, the saturation time was approximately $300 \mathrm{~min}$, corresponding to $80 \mathrm{~min}$ more than with a $1.2 \mathrm{~m}^{2}$ bag. To conclude, we can say that an increase in surface area led to a decrease in saturation time. So, to avoid sample contamination by humidity, the smallest possible surface area of Tedlar is required.

Table 5 Experimental results of humidity at several times (120 min, $240 \mathrm{~min}$ and $360 \mathrm{~min}$ )

\begin{tabular}{llll}
\hline \multirow{2}{*}{ Experiments } & \multicolumn{3}{l}{ Responses $(\mathrm{Y})$} \\
\cline { 2 - 4 } & $\mathrm{Y}_{120}$ & $\mathrm{Y}_{240}$ & $\mathrm{Y}_{360}$ \\
\hline 1 & 31.0 & 36.6 & 41.4 \\
2 & 23.7 & 31.0 & 37.0 \\
3 & 38.3 & 40.9 & 43.9 \\
4 & 27.3 & 34.2 & 39.3 \\
5 & 28.7 & 35.7 & 40.1 \\
6 & 30.7 & 37.1 & 41.4 \\
\hline
\end{tabular}

Experimental design

Humidity values were measured at three times $(120 \mathrm{~min}$, $240 \mathrm{~min}$ and $360 \mathrm{~min}$ ). Table 5 shows all the experimental data. Models were built with experiments 1 to 4 . Experimental design results (calculated coefficients that are significant) are summarised in Table 6.

As $b_{12}$ values are not significant, three models were built for the different exposure times:

$\mathrm{Y}_{120}=29.90-4.53 \mathrm{~V}+2.81 \mathrm{~S}$

$\mathrm{Y}_{240}=35.85-3.00 \mathrm{~V}+2.03 \mathrm{~S}$

$\mathrm{Y}_{360}=40.48-2.19 \mathrm{~V}+1.32 \mathrm{~S}$

In theses models, $\mathrm{V}$ and $\mathrm{S}$ are in coded values.

Table 6 Coefficient values for design models

\begin{tabular}{llrr}
\hline Coefficient & \multicolumn{3}{l}{ Different times (min) } \\
\cline { 2 - 4 } & 120 & 240 & \multicolumn{1}{c}{360} \\
\hline $\mathrm{b}_{0}$ & 29.90 & 35.85 & 40.48 \\
$\mathrm{~b}_{1}$ & -4.53 & -3.00 & -2.19 \\
$\mathrm{~b}_{2}$ & 2.81 & 2.03 & 1.32 \\
$\mathrm{~b}_{12}$ & -0.90 & -0.22 & -0.01 \\
\hline
\end{tabular}


Fig. 5 Deviation between experimental data and calculated data with the three models
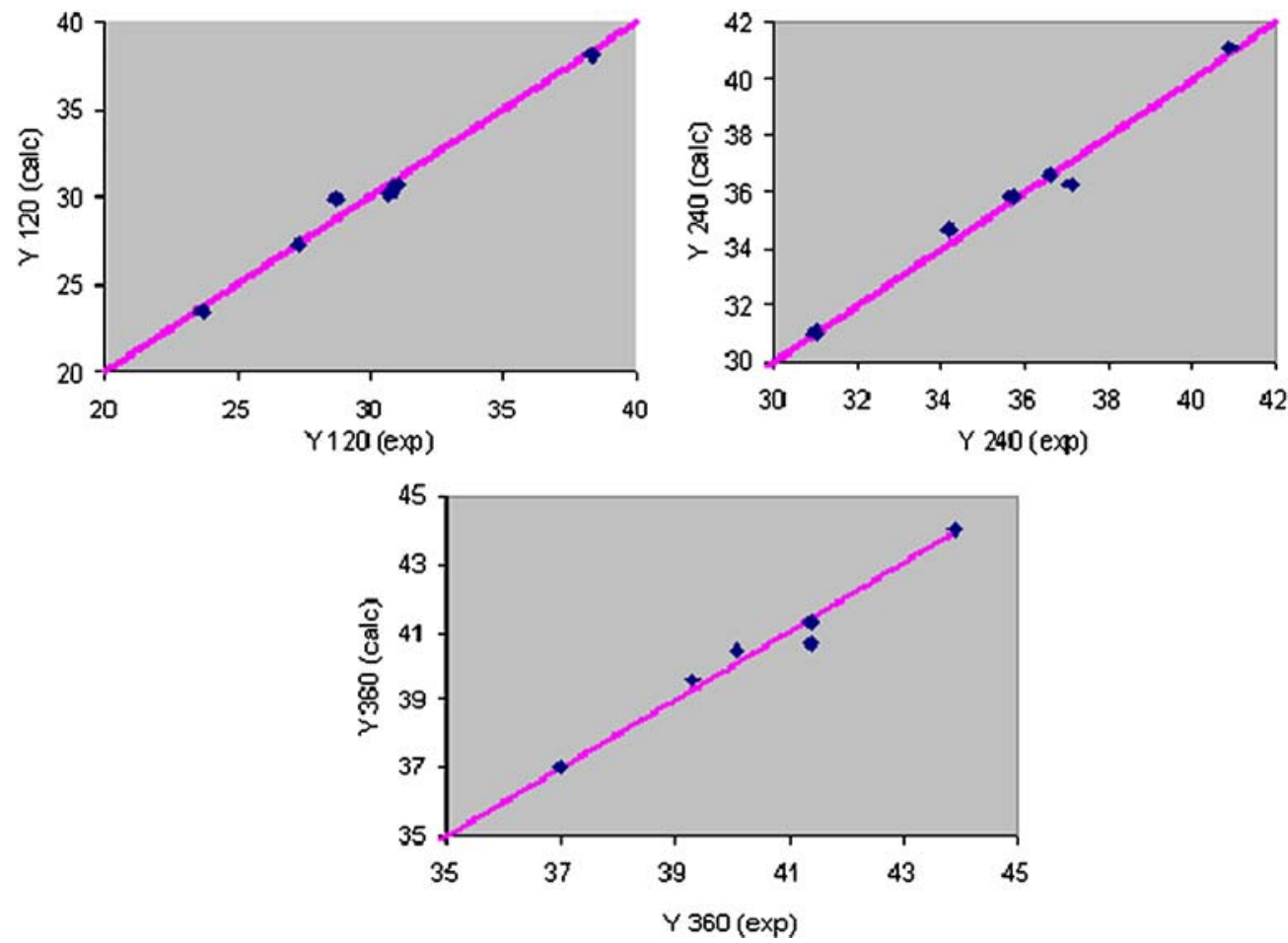

The b1 values indicate that an increase in volume could slow down the increase in humidity inside the Tedlar bags. In the same way, a small surface area reduces humidity evolution in the bag. With the studied variation range for both factors, the influence of volume seems to be a little more significant than that of surface area. That is why it is more important to fill bags as much as possible to limit a rapid increase in humidity.

After building a model, we compared the difference between experimental and calculated data. Fig. 5 shows the calculated values relative to experimental data. No significant difference could be observed, so it can be considered that the models fit reality quite well.

Evolution of humidity in double-layer Tedlar bags

An equivalent volume (15 l) was set in each internal bag of four double-layer bags. Different volumes were set in the

external bags to check the impact of the buffer volume on the humidity evolution in internal bags (Fig. 6). No evolution was observed for at least $100 \mathrm{~min}$ in any of the bags. Then, the humidity in the inner bag with the smallest outer volume increased quickly. The increase seemed to be correlated to the amount of air in the outer bag. The higher the initial dry air volume in the outer Tedlar bag, the lower the moisture increase in the inner bag, if the outer bags all had the same surface area.

Evolution of humidity in double-layer Tedlar bag with Drierite

Three different amounts of Drierite were set in the external bag of three double-layer bags to slow down the evolution of humidity in the internal bag. Fig. 7 shows the difference in moisture evolution between air in the room (approximately $15 \%$ ) and in the internal bag. It shows that $50 \mathrm{~g}$ of
Fig. 6 Evolution of humidity in internal bags with different volumes of dry air in external bags

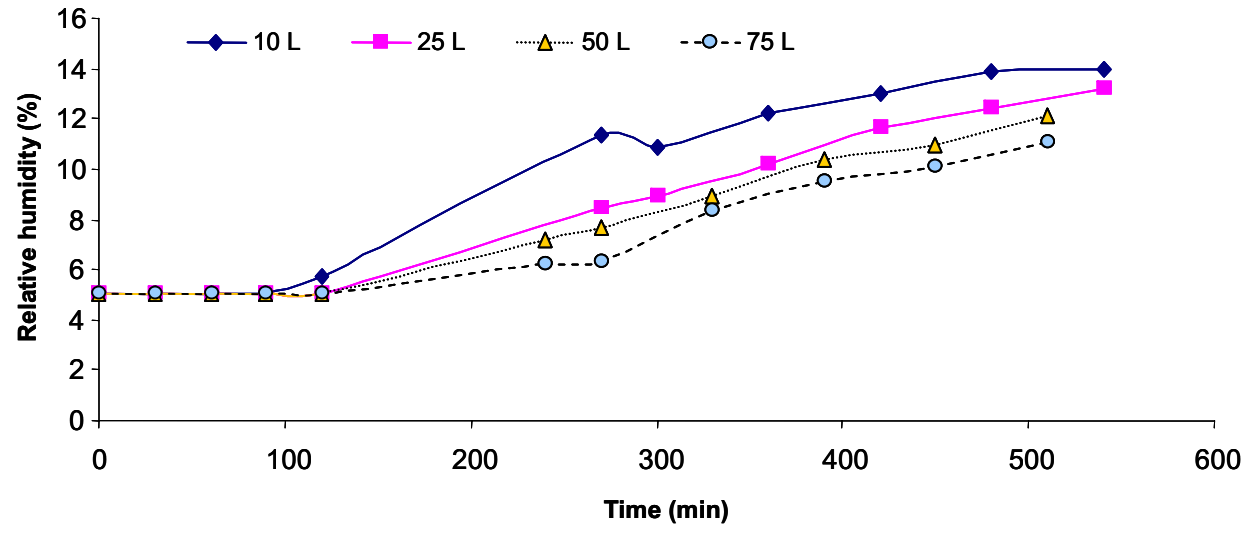


Fig. 7 Difference in evolution of moisture in internal bag and in room $(15 \%)$

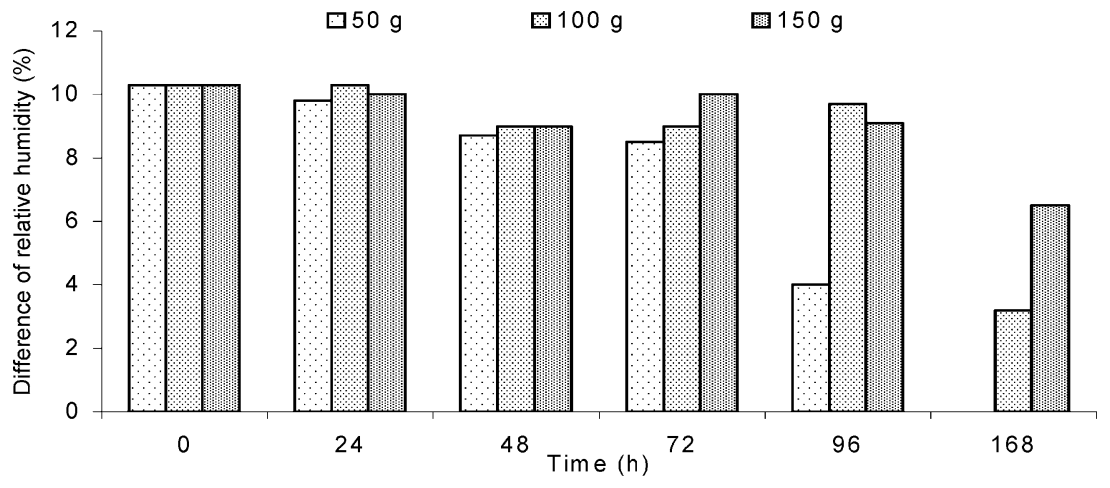

Drierite kept air dry in a Tedlar bag (internal bag) for 3 days in a room with humidity ao approximately $25 \%$. Increasing the amount of Drierite led to a rise in sample storage time. Such a desiccant can easily be used to keep an atmosphere dry (for example to avoid hydrolysis reactions) in the internal bag without direct contact with the Drierite. Because there is no direct contact, other desiccants could be chosen. It can be noticed that, in the case of higher humidity levels of ambient air, the amount of Drierite must be increased to keep the air sample dry for several days.

Evolution of VOC mixture in double-layer Tedlar bag with Drierite

Figure 8 shows the evolution in a real air sample in the internal bag of a double-layer Tedlar bag with Drierite in the external bag. The figure shows that, after a decrease from $40 \%$ to $15 \%$, the relative humidity in the internal bag stabilised for a long time (approximately 10 days). At the same time, the level of VOCs in the internal bag did not evolve very much, particularly in the first 3 days. The small decrease observed during the experiment could be explained by the exhaustion of the mixture in the Tedlar bag. This experiment shows the efficacy of double-layer Tedlar bags for decreasing the humidity of air samples without losses of VOCs due to the filtration by a desiccant or a membrane (Nafion for example) that can retain some polar compounds with trapped water.

\section{Conclusion}

The experiments carried out confirm that $50 \mu \mathrm{m}$-thickness Tedlar bags allow the diffusion of some molecules and particularly water. Firstly, sampling a maximum volume of air in a bag with the minimum surface area could slow down moisture increase. This can be confirmed by the experimental design that gives a model of humidity evolution in Tedlar bags. Secondly, a double-layer Tedlar bag with desiccant can slow down the moisture increase in the air sample (internal bag).

No significant pollutant level evolution was observed for $3 \mathrm{~h}$ when the Tedlar bag was filled with a VOC mixture. As humidity is a problem for studying air samples or for quantifying odour annoyance, this system seems to be an original and simple way to dry real air samples to enable analysis without modifying the sample, provided, of course, that the VOCs collected are stable during the experiment time.
Fig. 8 Evolution of moisture and $\mathrm{VOC}$ amount in the internal part of a double-layer Tedlar bag

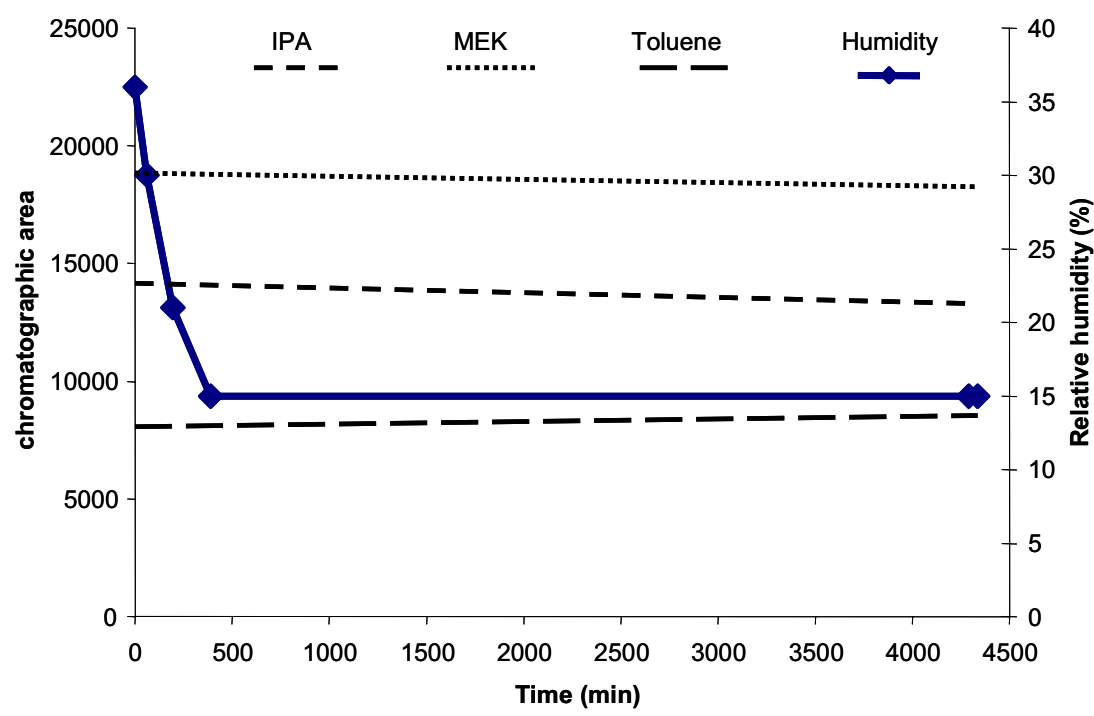




\section{References}

1. Colon M, Pleil JD, Hartlage TA, Lucia Guardani M, Helena Martins M (2001) Atmos Environ 35:4017-4031

2. Batterman SA, Zhang G-Z, Baumann M (1998) Atmos Environ 32:1647-1655

3. Rosen RT, Hiserodt RD, Fukuda EK, Ruiz RJ, Zhou Z, Lech J, Rosen SL, Hartman TG (2001) J Nutr 131:968S-971S

4. Zhang J, Smith KR, Ma Y, Ye S, Jiang F, Qi W, Liu P, Khalil MAK, Rasmussen RA, Thorneloe SA (2000) Atmos Environ $34: 4537-4549$

5. European Committee for Standardization (1999) Air qualitydetermination of odor concentration by dynamic olfactometry. EN 13725

6. Hoshika Y, Nishikitani M, Yokoyama K, Araki S (1997) Anal Sci 13:505-508

7. Van Harreveld AP (2003) J Air Waste Manage 53:51-60

8. Lee JH, Hwang SM, Lee D W, Heo GS (2002) B Kor Chem Soc 23:488-496
9. Choi YG, Ko DH, Kim HJ, Chung TH (2004) Water Sci Technol 49:329-334

10. McGarvey LJ, Shorten CV (2000) AIHA J 61:375-380

11. Fan ZH, Zhang JF, Fan CW, Pennise DM (2001) J Air Waste Manage 51:60-68

12. Sulyok M, Haberhauer-Troyer C, Rosenberg E, Grasserbauer M (2001) J Chromatogr A 917:367-374

13. Koziel JA, Pawliszyn J (2001) J Air Waste Manage 51:173-184

14. Tuduri L, Desauziers V, Fanlo JL (2003) Analyst 128:10281032

15. Lestremau F, Desauziers V, Fanlo JL (2004) Anal Bioanal Chem 378:190-196

16. Lattuati-Derieux A, Bonnassies-Termes S, Lavedrine B (2004) J Chromatogr A 1026:9-18

17. Tuduri L (2002) Analyse de traces de composés organiques volatils dans l'air par microextraction sur phase solide. Université de Pau et des Pays de l'Adour 